\title{
An Analysis of the Studies on Self-Efficacy in Mathematics Education in Turkey
}

\author{
Oktay Erbay (Corresponding author) \\ Hatay Mustafa Kemal University, Turkey \\ ORCID: 0000-0002-2698-0129, \\ E-mail: oktaymercimek@gmail.com \\ Guler Tuluk, \\ Kastamonu University, Turkey \\ ORCID: 0000-0002-3665-6699, \\ E-mail: gtuluk@kastamonu.edu.tr \\ Lutfi Incikabi, \\ Kastamonu University, Turkey \\ ORCID: 0000-0002-7912-780X, \\ E-mail: lincikabi@kastamonu.edu.tr
}

\begin{abstract}
The purpose of the study is to carry out a content analysis of research articles and theses published in Turkey between 2008-2020 on self-efficacy in mathematics education and to determine the trends of the mentioned studies. Document analysis were performed on 205 articles. A study classification form developed by Sozbilir, Kutu and Yasar (2012) was used to analyze the articles included in the study. The form consists of five sections: subject area, research patterns, data collection tools, sampling, and data analysis methods. Results show that self-efficacy studies were mainly quantitative studies and most of them selected middle school students or preservice teachers as sample. Especially qualitative studies suggested to the researchers.
\end{abstract}

Keywords: Mathematics education, self-efficacy, document analysis

DOI: $10.7176 / \mathrm{JSTR} / 7-10-09$

\section{Introduction}

As the strength of the constructivist perspectives increased in the cognitive and progressive process, the researchers 'interest in the students' thought and belief processes also increased and the focus of the research changed (Schunk, 2012). Socio-cognitive theory revealed the differences between learning and behavior (Zimmerman \& Schunk, 2003) and came up with two elements: Self-regulation and selfefficacy. Self-efficacy can be explained conceptually as a person's abilities that are thought to exist for learning or for performing a task. In social cognitive theory, Bandura (1982a, 1982b, 1986, 1997) examines human behavior in the frame of triple reciprocity, individual, behavior, and environment. These interrelated factors are considered as capacities used to organize the behaviors necessary for perceived self-efficacy, learning, or behavior. Studies on the relationship between behavior and selfefficacy (personal factors) showed self-efficacy affects task selection and decision behavior (Schunk, 1991, 2001; Schunk \& Pajares, 2002). While students working through tasks, such as working on exercise handouts, completing stages of term papers, they realize they are progressing towards the target behavior. This progress provides development indicators for the students to be convinced that they are doing well and increase their self-efficacy for continuous learning. The social environment may also play a role in the low self-efficacy of students with learning difficulties (Licht \& Kistner, 1986). These students may considered more incompetent by some teachers, and teachers' negative feedback affects the student's self-efficacy (Bryan \& Bryan, 1983).

\section{Literature Review}

Academic self-efficacy is a measurement of the students' faith in their competency to do an academic 75 I P a g e 
task in educational settings to gather achievement (Bong \& Skaalvik, 2003). One of the most considered academic field for self-efficacy studies is mathematics, and the first studies on self-efficacy were done in mathematics and science, for example, the first common scale used in mathematics selfefficacy belongs to Betz and Hackett (1983).

In social cognitive theory, cognitive modeling has an effect on students' self-efficacy and success while acquiring cognitive skills (Schunk, 1981). Considering the steps of a mathematics teacher who teaches division in the traditional way (Van De Walle et al., 2016), one of the factors affecting students' learning and practice through observation is self-efficacy. Thus, it affects behavior that they think the task is appropriate for their skills or believe they can do the task (if they could, I can do it too). A lot of situations about this kind of motivation can be observed in classes. Motivational effects depend to some extent on self-efficacy (Bandura, 1982b, 1997), and expectations affect self-efficacy. Research shows that specific tasks improve performance and objectives raise self-efficacy (Schunk, 1989a).

Self-efficacy is influenced by the targets set by individuals, feedback on progress to the target (Schunk, 1989b), and outcome expectations (Shell, Murphy \& Bruning, 1989). Observational learning is also influenced by the motivation, and it works on putting more goals, self-efficacy, and result expectations (Bandura, 1986, 1997). Cognitive research makes emphasis on attention, repetition, the use of learning strategies, and understanding. This situation helps mathematics education studies in determining the needs of the field, for example, the finding of various relationships among the attitude towards mathematics, self-efficacy, and self-regulation skills. To structure their mind, students should have several options for learning motivation and methods, the time needed for learning, level of the learning, the environment where learning takes place, and social conditions where they are influenced by (Zimmerman, 1994, 1998, 2000).

Regular review of articles published in academic journals is useful to see the current state of mathematics education research and to be aware of future trends (Ulutaş \& Ubuz, 2008). Ulutaş and Ubuz (2008) examined 129 studies published in the field of mathematics education. The majority of the studies were experimental studies conducted on primary school students or preservice teachers. These studies were mostly focused on the cognitive dimension, affective dimension, and teaching methods. They also used quantitative methods that administered using scales and surveys. It has been determined that subjects were numbers and geometry in most publications. Çiltaş, Güler, and Sözbilir (2012) investigated articles in the field of mathematics education using content analysis method. For this purpose, a total of 359 studies published in mathematics education have been examined in 32 different journals, 27 of them are national and 5 of them are in the Web of Science SSCI index. As a result of the research, they found there has been a great increase in mathematics education researches since 2002 , quantitative researches are preferred, learning studies are at the forefront as a research subject, single data collection tool is used more in the studies, and most of them use of percentage and frequency tables as the data analysis method. Incikab1 et al., (2017) conducted a content analysis of the studies which focus on mathematics education between 2009-2014. Findings revealed that the articles were not able to focus on learning areas clearly, most of them were non-experimental studies conducted dominantly on teacher training. In addition to these, it is determined that undergraduate students are preferred as the target audience, achievement tests and interview forms come to the fore as data collection tools. Tuluk and Delibaş (2019) investigated domestic research papers published between 2008-2018 on algebra and algebraic thinking, and it was determined that a large part of the studies were conducted on secondary school students. It was determined that most research was either surveys or case studies, used achievement or skill tests and interviews as the data collection tools, conducted descriptive analysis and content analysis methods. Biber and Er (2020), examined 94 master's degrees and 17 doctorate-level theses in the field of mathematics education in Turkey between 2001 and 2017. Results show that the semi-experimental method was the preferred method and the t-test was the preferred statistical data analysis tool.

When we examine the literature on mathematics and self-efficacy, mathematics self-efficacy studies come from the near past and it is difficult to give precise information about the beginning. When we focus on the Turkey-based work in self-efficacy, the number of studies in mathematics education possess a noticeable increase since 2008. Determining the trends in these studies will provide an opportunity to direct new researches as well as to see a big picture of self-efficacy studies in mathematics education.

Based on the above explanations, the current study aims to investigate self-efficacy research in mathematics education in Turkey between 2008 and 2020. Being in line with the aim, answers to the following research questions were sought.

76 | P a g e

www.iiste.org 
How is the distribution of the studies on self-efficacy in mathematics education between 2008-2020? What is the distribution of mathematics learning areas in the studies on self-efficacy in mathematics education between 2008-2020?

How are methodological specifications of the studies on self-efficacy in mathematics education between 2008-2020?

What objectives are targeted in the studies on self-efficacy in mathematics education between 20082020 ?

\section{Methodology}

The current study utilizes the document analysis method that examine printed sources collected for a specific purpose (Yıldırım \& Şimşek, 2008). Rummel (1964) and many researchers named this method as "document method", while Duverger (1973) called it "documentary observation". Karasar (2007, p. 183) expresses this method as a "systematic review of the existing records or documents as data sources". Document analysis is considered a type of qualitative research. In this respect, the research is designed according to qualitative research methods and techniques.

Determining the Studies to be Analyzed

Articles and thesis within the scope of this research reached from several databases such as Google Scholar, Ulakbim, ASOS, Turkish Education Index using keywords of Mathematics, self-efficacy, and mathematics self-efficacy". There were rare instances before 2008 such as a thesis in 2002 , an article in 2006, and another article in 2007. Hence we have restricted articles and thesis to the 2008-2020 timeframe and found 157 studies from the thesis database. The number of studies in the form of articles was found to be 355 . Then we eliminated some of these studies because some articles were produced from masters or doctoral theses. This elimination resulted in 205 distinct studies.

Data Analysis

The collected data were subjected to content analysis method. The purpose of the method is to gather deeper information about similarities and the differences in the content of collected data (İncikab1, et al., 2017). Organization and interpretation of this data helps us to understand and explain underlying concepts within the frameworks of the study (Yıldırım \& Şimşek, 2008).

"Publishing Classification Form" developed by Sözbilir, Kutu and Yaşar (2012) was used to analyze the articles included in the study. The form consists of seven sections as "information about paper, discipline area, subject of the paper, research methods, data collection tools, sample, and data analysis methods" (Sözbilir et al., 2012 p. 373). To determine the trends of the studies in the study, the criterion of "objectives of studies" has been added to the analysis units. Articles were analyzed by researchers according to the mathematical learning areas, method, data collection tools, sample, and data analysis methods.

First of all, information about the volume, number, authors of the article, and the publication language was entered as preliminary data. Then, the subject and method of the article, the data collection tools used in the article, and the methods used to analyze the data were determined. However, at these stages, it was seen that some articles lacked explanatory information, especially in the method of the research, data collection tools, and data analysis methods. In this case, the method of the article, the data collection tool type, and the data analysis methods were analyzed and coded by researchers. In the articles in which such information was renamed, the consensus of the researchers was paid attention.

During the analysis of the data, the researchers worked independently and analyzed the articles following the previously created criteria. The coding agreement between researchers is $93 \%$ according to Miles and Huberman's (1994) formula. The items causing the dispute were discussed again and a consensus was reached on the appropriate code.

\section{Findings}

Table 1 presents the distribution of the self-efficacy studies in mathematics education according to the years of publication. 
Table 1. Distribution of self-efficacy studies in mathematics between 2008 and 2020

\begin{tabular}{lll}
\hline Year & $\mathbf{n}$ & $\mathbf{\%}$ \\
\hline 2008 & 5 & 2,4 \\
2009 & 5 & 2,4 \\
2010 & 13 & 6,3 \\
2011 & 11 & 5,4 \\
2012 & 17 & 8,3 \\
2013 & 16 & 7,8 \\
2014 & 16 & 7,8 \\
2015 & 22 & 10,7 \\
2016 & 18 & 8,8 \\
2017 & 19 & 9,3 \\
2018 & 23 & 11,2 \\
2019 & 22 & 10,7 \\
2020 & 18 & 8,8
\end{tabular}

From Table 1, an increase in the number of the studies is noticeable. Moreover, self-efficacy studies in mathematics education have reached their top rate in 2018 and kept their popularity in 2019 and 2020. The distribution of the content domains of the self-efficacy studies in mathematics education in Turkey is given in Table 2.

Table 2. Distribution of the content domains of the self-efficacy studies

\begin{tabular}{lll}
\hline Content Domain & n & \% \\
\hline General & 116 & 56,6 \\
Algebra & 48 & 23,4 \\
Geometry and Measurement & 27 & 13,2 \\
Numbers and Operations & 8 & 3,9 \\
Probability and Statistics & 5 & 2,4 \\
Trigonometry & 1 & 0,5 \\
Total & 205 & 100,0 \\
\hline
\end{tabular}

According to Table 2, 23\% of the studies were in algebra content domain and $13 \%$ of studies were in geometry and measurement content domain. Numbers content domain included in $4 \%$, probability and statistics content domain included in $2 \%$, and trigonometry content domain included in $0.5 \%$ of these studies. More than half of the studies $(57 \%)$ are related to mathematics in general but cannot be included in a specific content domain. Self-efficacy in content domains such as probability and statistics, and trigonometry were explored by very few researchers

The research methods used in the self-efficacy studies in mathematics education are given in Table 3. 
Table 3. The distribution of research methodologies used in self-efficacy studies

\begin{tabular}{cl}
\hline Methodology & $\mathbf{n}$ \\
\hline Experimental & $35(\% 17,1)$ \\
Explanatory & 1 \\
Comparative & 1 \\
Correlational & 1 \\
Experimental & 3 \\
Survey & 2 \\
Single Subject & 1 \\
Semi Experimental & 24 \\
Weak Experimental & 2 \\
\hline None-Experimental & $157(\% 76,6)$ \\
Descriptive & 24 \\
Comparative & 5 \\
Correlational & 47 \\
Survey & 80 \\
Historically Analysis & 1 \\
\hline Mixed & $1(\% 0,5)$ \\
\hline
\end{tabular}

As shown in Table 3, the studies were mostly non-experimental (76.6\%) while the case study approach was preferred the least with a percentage of 0.5 . Survey studies were the most preferred research design among the studies in Turkey focusing on self-efficacy in mathematics education. Experimental studies $(17.1 \%)$ were in the second place among the research methodologies preferred in the math self-efficacy studies. Among the experimental studies, semi-experimental design was the most preferred one. Correlational design has also been paid attention to in math self-efficacy studies in Turkey. Approaches for quantitative analysis of the data obtained from self-efficacy studies in Turkey are provided in Table 4.

Table 4. Approaches for data analysis in the studies on self-efficacy in mathematics education between 2008-2020

\begin{tabular}{lll}
\hline Data Analysis Type & Analysis Made by & n \\
\hline Quantitative Data Analysis & & 197 \\
\hline & Difference in Means (parametric tests) & 105 \\
& Factor analysis & 30 \\
& Frequency/percentage Tables & 5 \\
& Content Analysis & 2 \\
& Correlation & 16 \\
& Non- parametric tests & 23 \\
& Mean/standard deviation & 4 \\
& Regression & 21 \\
\hline Qualitative Data Analysis & & 8 \\
\hline & Content Analysis & 2 \\
& Qualitative descriptive analysis & 5 \\
\hline
\end{tabular}

79 | P a g e 
Most studies utilized quantitative data analysis approaches $(n=197)$ while only eight studies utilized qualitative data analysis. Studies, which utilized quantitative analysis, mostly preferred T-tests, ANOVA and similar parametric test for statistical difference in means. Factor analysis, regression, correlation and non-parametric test were also carried out in the studies of self-efficacy in mathematics education. Qualitative data analysis, on the other hand, in the form of descriptive analysis $(n=5)$ and content analysis $(n=3)$ utilized only in 8 studies

The data collection tools of the targeted studies were provided in Table 5.

Table 5. Distribution of data collection tools in studies on self-efficacy in mathematics education between 2008-2020

\begin{tabular}{lll}
\hline Data Collection Tools & n & $\mathbf{\%}$ \\
\hline Perception / interest / attitude / etc, testing & 134 & 62,6 \\
Survey & 44 & 20,6 \\
Achievement test & 30 & 14,0 \\
Interview & 6 & 2,8 \\
\hline
\end{tabular}

When the table is examined, the majority of the studies utilized perception / interest / attitude / talent / personality tests as the means of data collection (62.6\%). Moreover, surveys $(20.6 \%)$ and achievement tests $(14 \%)$ are also among the highly preferred data collection tools. However, interviews (4\%) were chosen very few as a data collection tool.

In Table 6, the findings of the analysis of the participants and sample sizes are given.

Table 6. Participants and sample size distribution of the studies

\begin{tabular}{|c|c|c|c|c|c|c|c|}
\hline Participants & Sample s & & & & & & Total \\
\hline & $1-10$ & $11-30$ & $31-100$ & $101-300$ & $301-1000$ & $1000+$ & \\
\hline Early childhood students & & & & & 1 & & $1(0,5 \%)$ \\
\hline Primary school students & & 2 & 1 & 6 & 3 & 1 & $13(6,3 \%)$ \\
\hline Middle school students & 1 & 3 & 15 & 17 & 26 & 8 & $70(34,1 \%)$ \\
\hline High school students & & 1 & 9 & 4 & 12 & & $26(12,7 \%)$ \\
\hline Pre-service teachers & 2 & & 13 & 37 & 14 & & $66(32,2 \%)$ \\
\hline Teachers & & 1 & 4 & 13 & 5 & & $23(11,2 \%)$ \\
\hline Graduate students & & & 1 & 3 & & & $4(2,0 \%)$ \\
\hline Other & & & & 2 & & & $2(1,0 \%)$ \\
\hline Total & $3(1,5 \%)$ & $7(3,4 \%)$ & $43(21,0 \%)$ & $82(40,0 \%)$ & $61(29,8 \%)$ & $9(4,4 \%)$ & $205(100 \%)$ \\
\hline
\end{tabular}

It is evident from Table 6 that participants for the studies were mostly included middle school or undergraduate students while there were only a few studies in which graduate students and kindergarten students are used as samples. The scarcity of studies in primary education is also remarkable.

Table 6 also indicates that studies most of the time utilized a sample size in the range of 101-300. Moreover, the studies with small samples (less than 10 participants) or very large samples (more than 1000 participants) were rarely employed in the math related self-efficacy studies in Turkey.

The objectives of the studies conducted between 2008-2020 on self-efficacy in mathematics education were provided in Table 7 . 
Table 7. Analysis of the distribution of objectives of the studies on self-efficacy in mathematics education

\begin{tabular}{|c|c|c|c|c|c|c|c|c|c|c|c|c|c|c|}
\hline \multirow[b]{2}{*}{ Study works on } & \multicolumn{13}{|c|}{ Year } & \multirow[t]{2}{*}{ Tota } \\
\hline & & 定 & 을 & స్ & $\stackrel{\sim}{\sim}$ & $\stackrel{m}{\check{N}}$ & 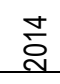 & $\stackrel{n}{2}$ & $\stackrel{\sim}{\sim}$ & స్ & $\stackrel{\infty}{\stackrel{2}{2}}$ & 음 & ర్సి & \\
\hline Scale development & 1 & & & 1 & 1 & & 1 & & 1 & & & 5 & 2 & 12 \\
\hline Perceived self - efficacy beliefs & 2 & 3 & 5 & 6 & 8 & 10 & 8 & 12 & 10 & 4 & 9 & 12 & 5 & 94 \\
\hline Content knowledge & & & 1 & & & 1 & 1 & 1 & 2 & 2 & 2 & 1 & 3 & 14 \\
\hline Mathematical skills & & & 3 & & 1 & 6 & 1 & 3 & 5 & & 3 & 3 & & 25 \\
\hline Teaching & 1 & 1 & & 5 & 6 & 3 & 2 & 6 & 3 & 2 & 4 & 5 & 2 & 40 \\
\hline Technological & 1 & 2 & 1 & 1 & 1 & & 4 & 2 & & & & 3 & & 15 \\
\hline Factors affecting self-efficacy & 2 & 2 & 6 & 4 & 5 & 2 & 4 & 10 & 6 & 5 & 13 & 1 & 9 & 69 \\
\hline Factors related with self-efficacy & & & 2 & & 3 & 4 & 3 & & 1 & 10 & 1 & 4 & 5 & 33 \\
\hline
\end{tabular}

According to Table 7, studies mostly aimed to investigate perceived self-efficacy beliefs ( $\mathrm{n}=94)$. Among the self-efficacy beliefs, a tendency of the investigation was observed towards math teaching efficacy beliefs. Moreover, other preferred objectives of the mathematics self-efficacy studies in Turkey included the factors affecting self-efficacy $(\mathrm{n}=69)$. The objectives of the studies also investigated the factors related to self-efficacy $(\mathrm{n}=33)$ or aimed scale development $(\mathrm{n}=12)$. Moreover, it is revealed from the table that the focus of research on mathematics self-efficacy varies by year. As an example for this situation, while factors related to self-efficacy were the focus of studies in 2017, studies in 2018 focused on factors affecting self-efficacy, and 2019 studies focused on the perceived self-efficacy beliefs.

\section{Discussion}

In this research, studies on mathematics self-efficacy in Turkey have been analyzed by all accounts of certain variables. Self-efficacy is the scope or strength of one's belief in the ability to complete their tasks and achieve goals. Psychologists have examined self-efficacy from various perspectives and have paid attention to various ways in the development of self-efficacy, self-efficacy dynamics, and deficiency in many different environments. It has been observed that the studies on Self-Efficacy between 2008-2020 have increased since 2010 .

is expected that there will be studies in the content domain of statistics, measurement, and data. However, there are also studies in which self-efficacy is an independent variable and its effects on a determined dependent variable are examined. It can be expected that studies will increase in mathematics content domains.

In a research process, the experimental method is generally preferred to measure variables and reveal cause-effect relationships depending on these variables. Experimental method is used in studies to collect quantitative data to examine the effect of a newly developed material or a new approach on student achievement in educational research (Çepni, 2018; Büyüköztürk et al., 2018). In full experimental research, an unnatural research environment is created and one or more control groups are selected to represent one or more experimental groups. The most important point in the selection of the groups is that the student distribution is done randomly. The main reason for this is to eliminate the problems that may arise from outside during the formation of the groups (Fraenkel \& Wallen, 2006). Even though full experimental research is best form of experimental research, when we look at the findings, full experimental method was preferred only in three studies. This situation can be explained by feasibility of randomization, and it is impractical to randomly assign students to experimental and control groups in schools where students already clustered when they start to schools (Taber, 2019).

In cases where it is not possible to randomly assign subjects to experimental and control groups, semiexperimental method is preferred (Cohen, Manion, \& Morrison, 2000). Since education in Turkey is

$\mathbf{8 1}$ I P a g e 
controlled by a central education ministry, it is almost impossible to implement full experimental research and researchers cannot create classes through random assignment, therefore previously created classes in schools are used as experimental and control groups in educational research (Gürbüz \& Şahin, 2014). In the findings of this study, semi-experimental methods were preferred by 24 studies. Single-subject research is a semi-experimental type of research in which findings related to only one subject are obtained and interpreted (Büyüköztürk et al., 2018). In the evaluated studies, the number of single-subject studies is only one.

Qualitative research can be defined as a research method that gives importance to the process rather than the result, provides detailed and in-depth research (Bogdan \& Biklen, 2007; Patton, 2002), and uses data collection tools such as interviews, observation, and document analysis. In a study to identify general trends in mathematics education dissertations, Tereci and Bindak (2019) found the most preferred method is qualitative research (38\%) among dissertations, and the number of quantitative $(32 \%)$ and mixed $(30 \%)$ studies were near to qualitative studies. This situation contradicts with our findings where majority of the studies in self-efficacy were quantitative. This can be explained by the nature of how self-efficacy is measured or observed. As discussed by Williams and Rhodes (2016), self-efficacy measure requires participants' own rating for their confidence level for a particular ability instead of participants' explanation. These ratings mostly represented by percentage levels. Since a selfefficacy measurement is reported by a number which is continuous in nature, most mathematics education researchers investigated to find its relationship with other constructs that represented by number in a particular range. These kind of investigations usually resulted in correlational studies or experimental studies which are the branches of quantitative studies.

In the study, the most frequently used methods of data analysis were the predictive techniques such as $\mathrm{t}$-test, ANOVA, and non-parametric tests in qualitative studies, while content analysis and descriptive analysis were frequently used techniques on qualitative data. The findings are parallel to Saracaloğlu et. al (2014).

There are also studies where self-efficacy is an independent variable and its effect on a determined dependent variable is examined. Teachers' knowledge level, students' mathematics achievement, attitude towards mathematics, problem-solving, and similar constructs have been related to selfefficacy. In this context, it is seen that self-efficacy is an element that can be associated with many individual and educational variables. Studies related to self-efficacy are increasing in teacher education programs, along with the fields of teaching specific mathematics content.

Our review showed that one third of the studies work on middle school students while another one third of the self-efficacy studies work on preservice teachers. Ratio of the studies, which work on preservice teachers, are close to the national ratio for educational studies. Göktaş et. al. (2012) found that $26 \%$ of the educational studies worked on undergraduate students while $11 \%$ of the studies worked on middle school students. Ratio of the middle school students were much higher in self-efficacy related studies in mathematics education. This ratio can be explainable by the structure of the Education Faculties in Turkey. Currently there are 13 programs for teaching high school mathematics (CHE, 2021a) while there are 76 programs in state universities and 9 programs in private universities for teaching middle school mathematics (CHE, 2021b). This numbers suggest that most of the mathematics educators work in primary school mathematics education departments. Therefore, it is a very natural result that most studies work on either preservice teachers or middle school students.

Examining the subjects of the studies showed that most studies chose mathematics as whole discipline as content domain. These studies generally tried to understand the relationship between mathematics self-efficacy and other constructs or how mathematics self-efficacy differed according to variables that separate sample in to independent groups. Algebra and geometry were also popular contents in the studies while probability, statistics and trigonometry was chosen by a small number of studies. This situation is also can be explainable by the dominancy of mathematics education programs for middle school students and distribution of content in middle school mathematics curriculum. A recent analysis showed that the least offered content domain was probability and statistics while trigonometry was not offered to middle school students (Biber \& Tuna, 2017)

In the studies examined in the study, it is seen that scale or questionnaires that make up the data set are frequently used as data collection tool. Saban (2009) stated in his research that education researchers mostly used surveys, scales, and inventories, however documents, observations and interviews are rarely used methods for data collection in studies related to multiple intelligence. Another general review conducted by Göktaş et al. (2012), named "Trends in Educational Research in Turkey: A Content Analysis", confirmed the findings of this research that most used data collection tools are

82 | P a g e

www.iiste.org 
surveys and questionnaires for interest/ attitude/ personality/ abilities. The scales not only facilitate the measurement process, but also determine the quality of the results obtained. Scientific development is based on measurement, and measurements made with sensitive measurement tools increase this development. Data in the cognitive domain becomes stronger with data in the affective domain. Cross validations in this field are valuable as an effort to contribute to mathematics education with the power it takes from psychological research.

When there is a suitable scale for the purposes of the study, which is validated on intended sample, researchers use this scale to collect data. However sometimes there is no appropriate scale that fits the purpose of the study or intended sample. Thus researchers try to develop a tailored scale for their purpose. In this aspect, mathematics-related self-efficacy scale development and implementation are discussed in various contexts in Turkey. These are mostly in the form of self-efficacy perception of preservice mathematics teachers and in-service teachers. In addition, it emerges in subjects such as developing a self-efficacy scale of middle school and high school students in mathematics fields (Aksu, 2008; Aslan \& Işıksal-Bostan, 2016; Aydın, Delice \& Kardeş, 2011; Günhan \& Başer 2007; Işıksal \& Aşkar, 2003; Karataş, \& Aslan-Tutak, 2017; Kılıç \& İncikabı, 2013; Koyuncu, Güzeller \& Akyüz, 2017; Mumcu, 2019; Özgen \& Bayram, 2018; Saraç \& Tutak-Aslan, 2013; Sevimli \& Aydın, 2017; Şan, 2013; Tataroğlu, 2009; Umay, 2001; Ünay, 2012; Yurt \& Sünbül, 2014;).

\section{Conclusion}

The present study investigated self-efficacy related studies in mathematics education in Turkey. Analysis showed that self-efficacy studies in mathematics education drastically increased from 5 to 22 between 2008 and 2015. After 2015, number of self-efficacy studies decreased a few and increased a few, and stayed in range of 18 to 23 . These self-efficacy studies are generally interested in mathematics as a whole discipline. Most of them were non-experimental studies, and tried to explain the relationship between self-efficacy and other psychological constructs. Most of the studies relied on statistical analysis for finding mean differences between groups. Relation between mathematics self-efficacy and mathematics achievement investigated by small numbers of studies. Typical sample size was between 100 and 300 while typical groups of interest were either middle school students of pre-service teachers. Although a few number of studies tried to develop a self-efficacy related scales, most of the studies were interested in perceived self-efficacy beliefs and factors affecting self-efficacy.

\section{Recommendations}

Previous research confirms that Self-efficacy beliefs and attitudes about mathematics are predictor variables for mathematics achievement (Randhawa, Beamer and Lundgerb's, 1993) and teacher selfefficacy has impact on students' mathematics achievement and attitudes toward mathematics (Küçükalioğlu \& Tuluk, 2020). Therefore, more experimental research is needed to find ways for increasing both teachers' and students' self-efficacy, and more qualitative research is needed to understand how teachers' self-efficacy is influenced.

Experimental studies on self-efficacy can be increased according to mathematics content domain in mathematics success, motivation, transferring, and other areas.

Experimental studies on large samples may help us to understand the efficiency of the methods that proposed to increase self-efficacy. However, studies that only have quantitative aspect do not help us to understand why or how a particular method is effective for increasing self-efficacy. Therefore we need more qualitative or mixed method studies to understand the nature of self-efficacy. One way to deeply examine the nature of self-efficacy is single subject studies.

Regression analysis is one of the correlational data analysis techniques that reveals how much of the change in the dependent variable explained by the independent variables. Structural equation modeling studies also a part of correlational studies which can help us to test causal relationships between variables in mathematics education studies. Therefore, we need more mathematics education studies, which utilize structural equation modeling, to reveal causal relationship between variables related to self-efficacy.

\section{Limitations}

This study investigated self-efficacy studies in Turkey, and these studies were limited to academic studies indexed by Google Scholar, Ulakbim, ASOS, and Turkish Education Index. Search keywords were only in Turkish and English languages and other languages were beyond the authors language skills.

83 I P a g e

www.iiste.org 


\section{References}

Aksu, H. H. (2008). Öğretmen adaylarının matematik öğretimine yönelik öz-yeterlik inançları [Prospective teachers' self-efficacy beliefs regarding mathematics teaching], Abant İzzet Baysal Üniversitesi Eğitim Fakültesi Dergisi, 8(2), 161-170

Arslan, O. \& Işsısal-Bostan, M., (2016). Origami in mathematics education: the development and validation of an origami-related self-efficacy scale. Elementary Education Online, 15(2), 548559. https://doi.org/10.17051/io.2016.06024

Aydın, E., Delice \& A., Kardeş, D. (2011). Matematik öğretmen adaylarına yönelik lineer denklem sistemleri öz-yeterlik algısı ölçeği [Development of a scale measuring mathematics teacher candidates' self-efficacy perceptions in solving systems of linear equations]. Turkish Journal of Computer and Mathematics Education, 2 (2), 158-180.

Bandura, A. (1982a). The self and mechanisms of agency. In J. Suls (Ed.), Psychological perspectives on the self (Vol. 1, pp. 3-39). Erlbaum.

Bandura, A. (1982b). Self-efficacy mechanism in human agency. American Psychologist, 37, 122147

Bandura, A. (1986). Social foundations of thought and action: A social cognitive theory. Prentice Hall.

Bandura, A. (1997). Self efficacy: Use exercise of control. Freeman.

Betz, N. E., \& Hackett, G. (1983). The relationship of mathematics self-efficacy expectations to the selection of science-based college majors. Journal of Vocational Behavior, 23, 329-345. https://doi.org/10.1016/0001-8791(83)90046-5.

Biber, A , \& Er, G . (2020). Matematik Eğitimi Alanında Yazılan Lisansüstü Deneysel Tezlerin İncelenmesi: Bir Meta-Analiz Çalışması [Examining Postgraduate Experimental Theses in Mathematics Education: A Meta-Analysis Study]. Muğla Sitkı Koçman Üniversitesi Eğitim Fakültesi Dergisi, 7 (1) , 24-34. https://doi.org/10.21666/muefd.646744

Biber, A. Ç. \& Tuna, A., (2017). Ortaokul matematik kitaplarındaki öğrenme alanları ve Bloom Taksonomisine göre karşılaştırmalı analizi [A comparative analysis of the exercise questions in secondary school mathematics books based on learning domains and Bloom's Taxonomy. Ondokuz Mayıs Üniversitesi Eğitim Fakültesi Dergisi, 36(1), 161-174. https://dergipark. org.tr/en/pub/omuefd/issue/30333/327396

Bogdan, R. C. \& Biklen, S. K. (2007). Qualitative research in education: An introduction to theory and methods (5th ed.). New York: Pearson Publishing.

Bong, M. \& Skaalvik, E.M. (2003). Academic self-concept and self-efficacy: how different are they really? Educational Psychology Review, 15, 1-40 https://doi.org/10.1023/A:1021302408382

Bryan, J. H. \& Bryan, T H. (1983). The social life of the learning disabled youngster. In J. D. McKinney \& L. Feagans (Eds,), Current topics in learning disabilities (Vol. 1, pp. 57-85). Abex.

Büyüköztürk, Ş., Kılıç-Çakmak, E., Akgün, Ö. E., Karadeniz, Ş. \& Demirel, F. (2018). Eğitimde bilimsel araştırma yöntemleri (25. Baskl) [Scientific Research Methods in education (25th Edition)]. Pegem Akademi.

CHE, Council of Higher Education (2021a, June 25). Net Wizard: Placement scores for high school mathematics teacher program in 2020. https://yokatlas.yok.gov.tr/netler-tablo.php?b=10147 
CHE, Council of Higher Education (2021b, June 25). Net Wizard: Placement scores for elementary school mathematics teacher program in 2020. https://yokatlas.yok.gov.tr/netlertablo.php?b=10103

Cohen, L., Manion, L. \& Morrison, K. (2000). Research Methods in Education. 5th Edition, Routledge Falmer. http://doi.org/10.4324/9780203224342

Çepni, S.,(2018), Araştırma ve Proje Çalışmalarına Giriş (8.Baskl) [Introduction to research and project studies (8th edition)], Pegem A Yayınc1lı.

Çiltaş, A., Güler, G. \& Sözbilir, M. (2012). Türkiye'de matematik eğitimi araştırmaları: bir içerik analizi çalışması [Mathematics Education Research in Turkey: A Content Analysis Study]. Kuram ve Uygulamada Eğitim Bilimleri, 12(1),565-580.

Duverger, M., (1973), Sosyal Bilimlere Giriş: Metodoloji Açısından [Introduction to the Social Sciences: With Special Reference to their Methods], (Ünsal Oskay, Trans.). Bilgi Yayınevi.

Fraenkel, J. R., \& Wallen, N. E. (2006). How to design and evaluate research in education (6th ed.). McGraw-Hill.

Göktaş, Y.,Hasançebi, F., Varışoğlu, B., Akçay, A., Bayrak, N., Baran, M. \& Sözbilir, M. (2012). Türkiye'deki eğitim araştırmalarında eğilimler: Bir içerik analizi [Trends in Educational Research in Turkey: A Content Analysis]. Educational Sciences: Theory \& Practice, 12(1), 443460. Retrieved from http://www.idealonline.com.tr/IdealOnline/makale/paper/1916

Günhan, B , Başer, N . (2007). Geometriye yönelik öz-yeterlik ölçeğinin geliştirilmesi [The development of self-efficacy scale toward geometry]. Hacettepe Üniversitesi Ĕ̈itim Fakültesi Dergisi, 33, 68-76

Gürbüz, S. \& Şahin F., (2014). Sosyal bilimlerde araştırma yöntemleri (2. Baskı) [Research methods in social sciences (Second edition) ]. Seçkin Yayıncılık.

Işıkal M. \& Aşkar P. (2003). İlköğretim Öğrencileri İçin Matematik ve Bilgisayar Öz-yeterlik Algısı Ölçekleri [The scales of perceived mathematics and computer self-efficacy for elementary students]. Hacettepe Üniversitesi Eğitim Fakültesi Dergisi 25, s: 109-118.

İncikabı, L., Serin, M..K., Korkmaz, S., ve İncikabı,S., (2017), Türkiye’ de 2009-2014 Yılları Arasında Yayımlanan Matematik Eğitimi Çalışmaları Üzerine Bir Araştırma [A Research on Mathematics Education Studies Published between 2009-2014 in Turkey], Adlyaman Üniversitesi. Ĕgitim Bilimleri Dergisi, 7(1), pp 1-19. https://doi.org/10.17984/adyuebd.325368

Karasar, N., (2007), Bilimsel Araştırma Yöntemi [Scientific Research Method], Nobel Yayınları.

Karataş, F. İ., Aslan-Tutak, F. (2017). Lise matematik öğretmenlerinin teknolojik pedagojik alan bilgileri ve teknolojiyi bütünleştirme öz yeterlilikleri [An examination of in-service secondary mathematics teachers' technological pedagogical content knowledge and their technology integration self-efficacy]. Mustafa Kemal Üniversitesi Sosyal Bilimler Enstitüsü Dergisi, 14(37), 180-198

Kılıç, Ç. \& İncikabı, L. (2013). Öğretmenlerin problem kurma ile ilgili öz-yeterlik inançlarının belirlenmesine yönelik ölçek geliştirme çalışması [A scale development study related to teachers' problem posing self-efficacy beliefs]. Dumlupınar Üniversitesi Sosyal Bilimler Dergisi, 35, 223-234. 
Koyuncu, I., Guzeller, C. O. \& Akyüz, D. (2017). The development of a self-efficacy scale for mathematical modeling competencies. International Journal of Assessment Tools in Education, 4(1), 19-36. https://doi.org/10.21449/ijate.256552

Küçükalioğlu, T., Tuluk, G., (2020), The Effect of Mathematics Teachers' Self-Efficacy and Leadership Styles on Students' Mathematical Achievement and Attitudes, Athens Journal of Education, 8(3): 221-238. https://doi.org/10.30958/aje.8-3-1

Licht, B. G., Kistner, J. A. (1986). Motivational problems of learning-disabled children: Individual differences and their implications for treatment. In J. K. Torgesen \& B. W. L. Wong (Eds.), Psychological and educational perspectives on learning disabilities (pp. 225-255). Academic Press.

Miles, M. B., \& Huberman, A. M. (1994). Qualitative data analysis: A sourcebook. Sage Publications.

Mumcu, H. Y. (2019). İlköğretim matematik öğretmen adaylarının matematiksel muhakeme özyeterlik inançlarının incelenmesi: Bir ölçek geliştirme ve uygulama çalışması [Investigation of primary school mathematics teacher candidates' mathematical reasoning self-efficacy beliefs: a scale development and implementation study]. Kırşehir Eğitim Fakültesi Dergisi, 20(3), 12391280.

Özgen, K. \& Bayram, B. (2018). Problem kurma öz yeterlik ölçeğinin geliştirilmesi [Development of problem solving self-efficacy scale]. 27th International Conference on Educational Sciences, pp. 2559-2562.

Patton, M. Q. (2002). Qualitative research and evaluation methods (3rd ed.). London: Sage Publications.

Randhawa, S. B., Beamer, E. J., \& Lundberg, I. (1993). Role of mathematics self-efficacy in the structural model of mathematics achievement. Journal of Educational Psychology, 85, 41-48.

Rummel, J. F., (1964), An Introduction to Research Procedures in Education, Second Edition. Harper \& Row.

Saban, A. (2009). Çoklu zekâ kuramı ile ilgili Türkçe çalışmaların içerik analizi [Content analysis of Turkish studies about the multiple intelligences theory]. Kuram ve Uygulamada Eğitim Bilimleri, 9(2), 833-876.

Saracaloğlu, A. S., Gündoğdu, K., Altın, M., Aksu, N., Kozağaç, Z. B., \& Koç, B. (2014). Yaratıcı düşünme becerisi konusunda 2000 yılı ve sonrasında yayımlanmış makalelerin incelenmesi [Analysis of articles published in the field of creative thinking skills after the year of 2000]. Adnan Menderes Üniversitesi Eğitim Fakültesi Eğitim Bilimleri Dergisi, 5(2), 62-74.

Saraç, A. \& Aslan-Tutak, F., (2013), The Relationship between Teacher Efficacy, and Students' Trigonometry Self-Efficacy and Achievement., International Journal for Mathematics Teaching \& Learning, 18 (1)

Schunk, D. H. (1981). Modeling and attributional effects on children's achievement: A self-efficacy analysis. Journal of Educational Psychology, 73, 93-105.

Schunk, D. IT. (1989a). Self-efficacy and cognitive skill learning. In C. Ames \& R. Ames (Eds.), Research on motivation in education. Vol.3: Goals and cognitions (pp. 13-44). Academic Ptess.

Schunk, D. H. (1989b). Self-eficacy and achievement behaviors. Educational Psychology Review, 1, 173-208.

86 | P a g e

www.iiste.org 
Schunk, D. H. (1991). Self-efficacy and academic motivation. Educational Psychologist, 26, 207231.

Schunk, D. H. (2001). Social cognitive theory and self- regulated learning. In B. J. Zimmerman \& D. H. Schunk (Eds.), Self-regulated learning and academic achievement: Theoretical perspectives (pp. 125-151). Lawrence Erlbaum Associates Publishers.

Schunk, D. H. (2012). Learning theories: An educational perspective (Sixth edition). Pearson.

Schunk, D. H., \& Pajares, F. (2002). The development of academic self-efficacy. In A. Wigfield Bi J. S. Eccles (Eds.), Development of academic motivation (pp. 15-31). Academic Press.

Sevimli, N. \& Aydın, E. (2017). İstatistik öz-yeterlilik inanç ölçeğinin Türkiye örneklemine uyarlanmas1 [The adaptation of the "statistics self-efficacy scale" to the Turkish sample], Journal of Education and Humanities: Theory and Practice, 8(16), 44-57.

Shell, D. F., Murphy, C. C., \& Bruning, R. H. (1989). Self-efficacy and outcome expectancy mechanisms in reading and writing achievement. Journal of Educational Psychology, 81(1), 91100. https://doi.org/10.1037/0022-0663.81.1.91

Sözbilir, M., Kutu, H., \& Yaşar, M. D. (2012). Science education research in Turkey: A content analysis of selected features of papers published. In J. Dillon \& D. Jorde (Eds). The World of Science Education: Handbook of Research in Europe (pp.341-374). Sense Publishers

Şan, İ. (2013). Matematik öğretmen adaylarının öğretimi planlama ve düzenleme yeterlikleri hakkında öz-yeterlik düzeyleri [The level of self-efficacy of prospective mathematics teachers about competencies for planning and organizing instruction]. Turkish Studies, 8(3), 517-537. http://doi.org/10.7827/TurkishStudies.4471

Taber, K. S. (2019). Experimental research into teaching innovations: responding to methodological and ethical challenges. Studies in Science Education, 55(1), 69-119. www.doi.org/10. $1080 / 03057267.2019 .1658058$

Tataroğlu, B. (2009). Matematik Öğretiminde Akıllı Tahta Kullanımının 10. Sınıf Öğrencilerinin Akademik Başarıları, Matematik Dersine Karşı Tutumları ve Öz- Yeterlik Düzeylerine Etkileri [The effect of utilizing the smart board in mathematics teaching on 10th grade students, their academic standings, their attitude towards mathematics and their self-efficacy levels]. [Master's thesis, Dokuz Eylül University]. Dokuz Eylül University Open Access. http://hdl.handle.net/20.500.12397/7238

Tereci, A, Bindak, R . (2019). 2010-2017 Yılları Arasında Türkiye'de Matematik Eğitimi Alanında Yapılan Lisansüstü Tezlerin İncelenmesi [Comparative analysis of post-graduate theses conducted between the years 2010-2017 in the field of mathematics education in turkey according to certain standards]. Muğla Sitkı Koçman Üniversitesi Ĕgitim Fakültesi Dergisi, 6(1) , pp 40-55. https://doi.org/10.21666/muefd.485737

Tuluk, G., Delibaş, M.E., (2019), 2008-2018 Yılları Arasında Cebir Alanında Yayınlanmış Makalelerin İncelenmesi [Investigations of Articles Related to Algebra Topic Published between 2008-2019], 4th International Symposium of Turkish Computer and Mathematics Education, 2628 September 2019, İzmir.

Ulutaş, F, Ubuz, B . (2008). Matematik Eğitiminde Araştırmalar ve Eğilimler: 2000 ile 2006 Yılları Arası [Research and Trends in Mathematics Education: 2000 to 2006]. İlkögretim Online, 7 (3), 614-626. https://dergipark.org.tr/tr/pub/ilkonline/issue/8600/107083 
Umay, A. (2001). İlköğretim matematik öğretmenliği programının matematiğe karşı özyeterlik algisina etkisi [The effect of the primary school mathematics teaching program on the mathematics self-efficacy of students]. Journal of Qafqaz University, no. 8.

Ünay, E. (2012). Bireysel destek eğitiminin kaynaştırma öğrencilerinin matematik başarıları ve özyeterlilik algıları üzerindeki etkililiği [The effect of personal support education on inclusive students' mathematics achievement and mathematics self-efficay]. [Master's thesis, Dokuz Eylül University]. Dokuz Eylül University Open Access http://hdl.handle.net/20.500.12397/6758

Van De Walle, J., Karp, K.S. \& Bay-Williams, J. M. (2016). Ilkokul ve ortaokul matematiği: gelişimsel yaklaşımla ögretim [Elementary and middle school mathematics: Teaching developmentally]. (S. Durmuş, Trans.). Nobel Yayınları.

Williams, D. M., \& Rhodes, R. E. (2016). The confounded self-efficacy construct: conceptual analysis and recommendations for future research. Health psychology review, 10(2), 113-128. https://doi.org/10.1080/17437199.2014.941998

Yıldırım, A., \& Şimşek, H., (2008), Sosyal Bilimlerde Nitel Araştırma Yöntemleri (5. Baskı) [Qualitative Research in Social Sciences (5th edition) ]. Seçkin Yayınları.

Yurt, E., \& Sünbül, A. M., (2014). Matematik öz-yeterlik kaynakları ölçeğinin Türkçeye uyarlanmas1 [The adaptation of the sources of mathematics self-efficacy scale for Turkish context]. Eğitim ve Bilim, 39(176), 145-157. http://doi.org/10.15390/EB.2014.3442

Zimmerman, B. J., \& Schunk, D. H, (2003). Albert Bandura: The scholar and his contributions to educational psychology. In B. J. Zimmerman \& D. H. Schunk (Eds.), Educational psychology: A century of contributions (pp. 431-457). Erlbaum.

Zimmerman, B. J, (1994). Dimensions of academic self- regulation: A conceptual framework for education. In D. H. Schunk Sc B.J. Zimmerman (Eds.), Self-regulation of learning and performance: Issues and educational applications (pp. 3-21). Erlbaum.

Zimmerman, B. J. (1998). Developing self-fulfilling cycles of academic regulation: An analysis of exemplary instructional models. In D. H. Schunk \& B. J. Zimmerman (Eds.), Self-regulated learning: From teaching to self-reflective practice (pp. 1-19). Guilford Press.

Zimmerman, B.J. (2000). Attaining self-regulation: Asocial cognitive perspective. In M. Boekacrts, P. R. Pintrich, \& M. Zcidner (Eds.), Handbook of self-regulation (pp. 13-39). Academic Press. 